\title{
The Role of the Bystander Effect on Body Shaming Intensity in Psychology Students in Malang City
}

\section{Safira Yusri Maulani*, Aryudho Widyatno, Imanuel Hitipeuw, and Yudi Tri Harsono}

Psychology, State University of Malang, Malang

ORCID

Safira Yusri Maulani; https://orcid.org/0000-0002-8897-3768

Corresponding Author: Safira

Yusri Maulani; email:

safira.9g28@gmail.com

Dates

Published 28 January 2022

Publishing services provided by

Knowledge $\mathrm{E}$

(c) Safira Yusri Maulani et al. This article is distributed under the

terms of the

Attribution License, which

permits unrestricted use and redistribution provided that the

original author and source are credited.

Selection and Peer-review under the responsibility of the ICoPsy Conference Committee.
Abstract. Body shaming is when the form of one's body is criticized, either intentionally or not. Body shaming is considered a form of verbal bullying. In body shaming situations, there are actors, victims, and bystanders. A bystander can be an amplifier for the actors to keep carrying out the body shaming. This is called the bystander effect and it occurs when bystanders keep silent and do not support the victim of the body shaming. Body shaming is found commonly on university campuses. Psychology students are no exception, even though they are assumed to possess sensitivity and understanding of body shaming. This study aimed to examine the role of the bystander effect on the intensity of body shaming. A quantitative descriptive correlation approach was used and the research instruments employed were the bystander effect scale and the intensity of body shaming scale. 100 psychology students in Malang city participated. Simple linear regression was used to analyze the data. The results indicated that the bystander effect played a significant role in the intensity of body shaming. The contribution of the bystander effect variable to the body shaming intensity variable was $5.3 \%$.

Keywords: body shaming, bystander effect, students

\section{Introduction}

Physical appearance has been made as one of the many components taking certain important role in daily activities. Physical appearance triggers a subjective assessment of the society developing into standard criteria. Standard criteria many take place is the ideal appearance of body in a form the harmony between a person's weight and height and skin color. An ideal body in women [1] is characterized by a thin body shape. In addition, for men, the ideal body is characterized by a large muscular body shape, slim, and a flat stomach.

The direct result of these criteria standards have made people to force their bodies accordingly to the standards that apply in society. In addition, they will participate in commenting, criticizing, and physically insulting others. These actions, whether intentional

\section{G OPEN ACCESS} or unintentional, can be categorized as verbal bullying. [2] Data from the Indonesian 
Child Protection Commissioner in 2020, bullying that occurred both at school and on social media reached 2,473 cases and continues to increase.

Bullying is a term taken from the word bully which is defined as a bully or a person who annoys others who are weaker. [3] three types of bullying behavior consist of: first, verbal bullying by insulting and berating; Second, physical bullying by hitting, grabbing, and slapping; Third, gestural bullying, by looking cynically or away.

Bullying often occurs in the world of education. In fact, Indonesia is included in the category of "emergency bullying in schools" therefore, urgent intervention is needed [4]. The 2014 study of the National Consortium for Character School Development found that every school in Indonesia had cases of bullying and the most common were verbal and psychological/mental bullying. [5] verbal bullying works by offending the victim's feelings in the form of reproach, nicknames, insults, cruel criticism, etc.

[6] Revealed that for every episode of bullying, there are at least two parties involved, namely the perpetrator and the victim. However, most cases of bullying will involve witnesses or bystanders who can encourage the abuser through verbal support, or remain silent and impartial, or come forward and try to stop the bullying situation [6]. Thus, one indicator that strengthens bullying behavior is the presence of a bystander (observer) when the incident occurred. [7] Bullying behavior can increase due to the presence of other people who witness and at the scene.

Bystander chose to remain silent and not defending because he was afraid of the bullies [5]. However, bystander behavior in bullying situations actually shows concern for the victim and on the other hand they are also worried about the consequences when defending the victim, so it can be said that the bystander is more worried about the social consequences than the victim's situation [8].

The reason for the perpetrators of bullying is the feeling of power [9]. Bullies feel proud to be seen as great and feared by others who witness them bullying. Bullies consider their behavior to help improve their status in peer groups [10]. In addition, bullies also have a feeling that they are strong and confident so they enjoy a social status seen as popular among their peers [11].

If the bystander is an observer who is in the setting of bullying behavior that appears, then the bystander effect is a situation resulting from the presence of the audience in the bullying behavior which actually allows the person to provide assistance to strangers [12]. The bystander effect as the thought that someone else has already given a helping hand therefore they will not do anything to help people who are in trouble [13]. The bystander effect indicates that the presence of other people can inhibit helpful behavior at an ongoing event. 
The bystander effect can occur in any situation, including body shaming situations. Body shaming is included in verbal bullying that can erode one's self-confidence [14]. Body shaming will continue to increase if it is allowed to continue. The process of body shaming consisting of perpetrators, victims, and bystanders. Although the perpetrator and the victim are directly related in the process, the presence of a bystander can be a reinforcement and support for the perpetrator to take repeated actions. In other words, the perpetrator's perception of bystander affects the increase in bullying behavior. This is evidenced in Festinger's research in [15] that bullies perceive bystanders as supporting their behavior and that support becomes a reward. Thus, the presence of a witness or bystander in a bullying situation can trigger the repetition of the action.

Body shaming is an attitude in assessing the body shape of oneself or others. Body shaming is a form of behavior evaluating the appearance of oneself and others against the internalization of ideal beauty standards [16]. Body shaming is criticizing or giving negative comments to someone's physical form intentionally or not [17]. It can be interpreted that body shaming is an act of humiliating the body by making embarrassing comments and criticisms about a person's size or weight [18]

Body shaming can be carried out by people closest to people who are not recognized, so it often occurs in the surrounding environment without realizing it. Examples of body shaming are mocking a fat or thin body, black skin color, pug, short stature, chubby cheeks, big or slanted eyes, etc. Body shaming is closely related to body image which is defined as the perception of the ideal body according to society, which raises standards of beauty.

Body shaming has entered the category of worrying. [19] Mentioned in his article that the Fit Rated Study on 1,000 men and women resulted in $92.7 \%$ of women and $86.5 \%$ of men experiencing body shaming. Meanwhile, the results of the Body Peace Resolution Survey conducted by Yahoo! Health shows that body shaming is more experienced by women than men as much as $94 \%$. Meanwhile, in Indonesia body shaming is a case that is often found. The National Police Headquarters in [20] explained that there were 966 cases of physical humiliation or body shaming handled by police from all over Indonesia throughout 2018.

Body shaming that is continuously carried out can have an impact on one's selfesteem, increase isolation, withdraw oneself, make a person vulnerable to stress, depression, and lack of confidence [17]. Body shaming activities can also make victims feel anxious, embarrassed, angry, and hate themselves. In addition, victims will feel that their existence is not accepted, due to their body shape that does not comply with community criteria. [21] Mentioned the impact of body shaming is a strict diet, the 
emergence of obsessive compulsive behavior (often checking one's appearance and weighing weight), generating negative emotions (angry, shame, hate, anxiety, fear, etc.), triggering mental disorders, (eating disorders and body dysmorphic disorder), as well as withdrawing from the social environment.

Factors that cause perpetrators to carry out body shaming are feelings of envy and lack of confidence in what they have, so they tend to vent it by doing these actions because they are not happy to see other people happy. Meanwhile, according to Verauli in [17] one of the factors that cause body shaming in Indonesia is the in-group cultural climate, a habit that tends to make someone treat others like brothers, both known and unknown people, thus making one finds it natural to comment on the shape of another person's body.

Body shaming still exists in society, including among students. Students are individuals who are in the process of gaining knowledge or studying and are registered to be undergoing education at one of the universities such as academics, polytechnics, high schools, institutes, and universities [22]. Students are individuals who are experiencing a period of growing up (emerging-adulthood) at an age range of 18-25 years. One of the developmental tasks of early adulthood is finding a life partner, which causes the need to appear attractive in front of others. For this reason, physical appearance becomes something important to pay attention to so that it can trigger the emergence of body shaming behavior.

This study uses the subject of psychology students because researchers still see a tendency for psychology students to take body shaming actions and a low level of concern to help body shaming victims get out of the situation. Based on the initial interviews that have been conducted, it was found that psychology students at a university in Malang had witnessed or heard of body shaming in their surroundings, however, they admitted that they did not help and were silent. Several students said that they would help defend the victim if they were close to the perpetrator. In addition, psychology students are also proven to be perpetrators of body shaming. Whereas psychology students should have sufficient sensitivity to the issue of body shaming, including the impact of body shaming.

\section{Literature Review}

Bullying is a word that comes from bully which means as a bully or a person who annoys others who are weaker. Bullying as negative behavior that involves four elements consisting of an imbalance of power, the desire to injure, the emergence of threats of 
continuous aggression, and the presence of terror [5]. The forms of bullying [5] consisted of physical bullying, verbal bullying, and psychological bullying.

Body shaming is a form of verbal bullying. [17] Added that body shaming is criticizing or giving negative comments to someone's physical form intentionally or not. The behavioral forms of body shaming [23] are verbal body shaming, written body shaming, and action body shaming. Body shaming is influenced by several factors. Devie in [17] revealed that the factors that influence body shaming are patron client culture, patriarchy, post-colonial, and lack of knowledge about body shaming. Veraulli in [17] explained that the causes of Indonesians doing body shaming are the in-group cultural climate, high self-confidence, and low self-esteem.

In a body shaming situation, there are three parties involved, namely the perpetrator, victim, and bystander. Bystander is one indicator that can strengthen bullying behavior. [7] Stated that bullying behavior can increase due to the presence of other people who witnessed and were at the scene. If the bystander is an audience present at an event, then there is a social phenomenon called the bystander effect. The bystander effect is a situation when people are only spectators of an event that requires assistance, but do not provide assistance because they think that other people can provide help.

[15] Research on junior high school students in Makassar with similar variables, it was stated that the bystander perception of the intensity of bullying showed a positive influence. It can be said that the perpetrator's perception of the bystander can increase the intensity of bullying.

\section{Method}

This study used a descriptive correlational quantitative approach. This research is descriptive with the aim of providing an overview of the research subject based on the sample. This study also aims to see the significant role of the independent variable (bystander effect) on the dependent variable (intensity of body shaming). The population used were active students majoring in psychology from various universities in Malang City with a total of 5102 students. This study used a sampling technique in the form of accidental sampling which is included in non-probability sampling with subject criteria, namely (1) active psychology students in Malang city (2) aged 18-25 years (3) have done body shaming actions.

This study used two instruments consisting of a bystander effect scale and a body shaming intensity scale. The bystander effect is the perception of the perpetrator in assessing the presence and intervention of the bystander in body shaming events. 
The bystander effect scale is based on the bystander behavior model described by Latane \& Darley in [24] which consisted of the behavior of others in being aware of the situation, interpreting problems, having personal responsibility, and determining the type of assistance. The bystander effect scale has 20 favorable items and 18 unfavorable items. Reliability was calculated using Cronbach's Alpha with a reliability coefficient of 0.924.

The intensity of body shaming is the frequency of criticizing or giving negative comments on a person's physical form intentionally or not. The body shaming intensity scale is based on the form of body shaming behavior [23] which included oral body shaming, written body shaming, and action body shaming. Body shaming intensity scale has 17 favorable items and 15 unfavorable items. Reliability was calculated using Cronbach's Alpha with a reliability coefficient of 0.948 .

This research passed the assumption test which consisted of normality test and linearity test. The assumption test was carried out using SPSS for Windows with the Kolmogorov-Smrinov formula. The data can be said to meet if the significance value was more than 0.05 ( $p>0.05)$. If the assumption test has been met, then the next step is to test the hypothesis with a simple linear regression analysis technique.

\section{Research Results}

\subsection{Descriptive Analysis}

Descriptive analysis was carried out to see the general description of 100 psychology students in Malang city regarding the bystander effect and the intensity of body shaming. The following is the demographic data of psychology students from various universities in Malang, aged between 18 to 25 years.

\section{1. (a) Bystander Effect}

The following is the bystander effect data found through the bystander effect scale which consists of four bystander models proposed by Latane \& Darley in [24].

Based on the table above, it can be seen that the bystander effect on 100 psychology students in Malang City in hypothetical data has the lowest score of 38 and the highest score of 190. The average obtained is 114 with a standard deviation of 25.3. Meanwhile, on empirical data, the lowest score is 51 and the highest score is 168 . The average obtained is 101.92 with a standard deviation of 23.3. The bystander effect categorization data from psychology students in Malang City can be presented as follows: 
TABLE 1: Demographic Data of Malang City Psychology Students.

\begin{tabular}{|c|c|c|c|c|}
\hline No & Note & Criteria & Total & Percentage \\
\hline \multirow[t]{9}{*}{1} & Age & 18 yrs old & 3 & $3 \%$ \\
\hline & & 19 yrs old & 12 & $12 \%$ \\
\hline & & 20 yrs old & 14 & $14 \%$ \\
\hline & & 21 yrs old & 27 & $27 \%$ \\
\hline & & 22 yrs old & 32 & $32 \%$ \\
\hline & & 23 yrs old & 7 & $7 \%$ \\
\hline & & 24 yrs old & 3 & $3 \%$ \\
\hline & & 25 yrs old & 2 & $2 \%$ \\
\hline & & Total & 100 & $100 \%$ \\
\hline \multirow[t]{7}{*}{2} & $\begin{array}{l}\text { Origin } \\
\text { University }\end{array}$ & of State University of Malang & 36 & $36 \%$ \\
\hline & & $\begin{array}{l}\text { University of Muhammadiyah } \\
\text { Malang }\end{array}$ & 14 & $14 \%$ \\
\hline & & Brawijaya University & 17 & $17 \%$ \\
\hline & & Merdeka University Malang & 15 & $15 \%$ \\
\hline & & UIN Maulana Malik Ibrahim & 10 & $10 \%$ \\
\hline & & Gajayana University & 8 & $8 \%$ \\
\hline & & Total & 100 & $100 \%$ \\
\hline
\end{tabular}

TABLE 2: Descriptive Analysis Results of Bystander Effect.

\begin{tabular}{|l|l|l|l|l|l|l|l|l|} 
Variable & \multicolumn{4}{c}{ Hypothetic Data } & \multicolumn{4}{c|}{ Empiric Data } \\
& Min & Max & SD & Mean & Min & Max & SD & Mean \\
\hline Bystander Effect & 38 & 190 & 25,3 & 114 & 51 & 168 & 23,3 & 101,92 \\
\hline
\end{tabular}

Based on the table above, it can be seen that the results of research conducted on 100 Psychology students in Malang City were 3 psychology students with a percentage of $3 \%$ with a high level of bystander effect, 63 psychology students with a percentage of $63 \%$ with a moderate level of bystander effect and 34 psychology students with a percentage of $34 \%$ has a low level of bystander effect.

TABLE 3: Categorization of Bystander Effect Score.

\begin{tabular}{l|l|l|l} 
Categorization & Categorization Limit & N & Percentage \\
\hline Low & $X<89$ & 34 & $34 \%$ \\
Intermediate & $89 \leq X<139$ & 63 & $63 \%$ \\
High & $139 \leq X$ & 3 & $3 \%$
\end{tabular}


TABLE 4: Analysis Results of Body Shaming Intensity.

\begin{tabular}{l|l|l|l|l|l|l|l|l|l} 
Variable & \multicolumn{3}{c}{ Hypothetic Data } & \multicolumn{4}{c}{ Empiric Data } \\
\cline { 2 - 5 } & Min & Max & SD & Mean & Min & Max & SD & Mean \\
$\begin{array}{l}\text { Body Shaming } \\
\text { Intensity }\end{array}$ & 160 & 21,3 & 96 & 38 & 155 & 32,7 & 93 \\
\hline
\end{tabular}

TABLE 5: Score Categorization of Body Shaming Intensity.

\begin{tabular}{l|l|l|l} 
Category & Categorization Limit & N & Percentage \\
\hline Low & $X<75$ & 34 & $34 \%$ \\
\hline Intermediate & $75 \leq X<117$ & 41 & $41 \%$ \\
High & $117 \leq X$ & 25 & $25 \%$ \\
\hline
\end{tabular}

\subsection{Intensity of Body Shaming}

Body shaming intensity data was found through the calculation of the body shaming intensity scale which consists of three body shaming behaviors proposed [23].

Based on the table above, it can be seen that the intensity of body shaming in 100 psychology students in Malang City in the hypothetical data had the lowest score of 32 and the highest score of 160 . The average obtained was 96 with a standard deviation of 21.3. Meanwhile, in empirical data, the lowest score is 38 and the highest score is 155. The average obtained is 93 with a standard deviation of 32.7. The data on the categorization of the intensity of body shaming from psychology students in Malang city can be presented as follows:

Based on the table above, it can be seen that the results of research conducted on 100 Psychology students in Malang City are 25 psychology students with a percentage of $25 \%$ with a high level of body shaming intensity, 41 psychology students with a percentage of $41 \%$ with a moderate level of body shaming intensity and 34 psychology students with a percentage of $34 \%$ have a low level of body shaming intensity.

\subsection{Assumption Test}

\section{Normality Test}

TABLE 6: Normality Test Results.

Variable
Bystander Effect
Body Shaming Intensity

$p$
0,184
0,061

Conclusion

Normally Distributed

Normally Distributed 
TABLE 7: Linearity Test Results.

\begin{tabular}{l|ll} 
Variable & \multicolumn{3}{|c}{ Deviation from Linearity } \\
\cline { 2 - 3 } & F & p \\
\hline Bystander Effect -Body Shaming Intensity & 1,023 & 0,476
\end{tabular}

From the table data above, it can be concluded that the bystander effect variable obtains $p$ of $0.184>0.05$ so it can be said that the bystander effect variable is normally distributed. Meanwhile, the body shaming intensity variable obtained a p of $0.061>$ 0.05 so it can be said that the body shaming intensity variable is normally distributed.

\subsubsection{Linearity Test}

Based on the table above, between the bystander effect variable and the intensity of body shaming, we obtained $F$ deviation from linearity of 1.023 . The table above also shows that the significance value is $0.476>0.05$ so it can be said that there is a linearity or role between the bystander effect and the intensity of body shaming.

\subsection{Hypothesis Test}

The hypothesis test of this study was conducted using a simple linear regression analysis technique which aims to measure the magnitude of the role of one independent variable or independent variable on a dependent variable or dependent variable. The following are the results of hypothesis testing using simple linear regression in this study:

1. Obtained an $R$ square value of 0.053 with a standard error of 32.05 , indicating that $5.3 \%$ of the variable intensity of body shaming can be explained by the variable of bystander effect.

2. The results of the ANOVA test or $F$ test obtained an $F$ value (1.98) of 5.49 with $p$ $<0.05$ so it can be said that the bystander effect can be used as a predictor of body shaming intensity.

3. The value of $t$ was 2.34 with $p<0.05$ and $=0.23$ indicating that the bystander effect can significantly predict the intensity of body shaming. In addition, this study also calculated the regression equation with the formula of $Y=a+b X$ therefore the results were $59.927+0.323$ bystander effect, so this shows that if a person does not have a bystander effect at all, then the intensity of body shaming was 59.927, while every one point increased bystander effect a person can increase the intensity of body shaming by 0.323 . 


\subsection{DISCUSSION}

The results showed that the bystander effect had a significant role in the intensity of body shaming in psychology students in Malang City. This proves that the perception of body shaming perpetrators on the presence of bystanders can increase the occurrence of body shaming actions in the campus area. The results of this study are reinforced by the research of [7] which explained that bullying behavior can increase due to the presence of bystanders who witness and attend when bullying situations occur. [25] Also added that the act of bullying is very dependent on the reaction of the bystander which consisted of two types of bystanders, namely passive bystanders or supportive bystanders by cheering.

This study focuses on the perpetrator's perception of the bystander which turns out to have a role in increasing body shaming actions. Perpetrators viewed that bystanders often do not provide any assistance when the victim experiences body shaming. This is what makes the perpetrators feel that their actions are reasonable to be repeated. Body shaming perpetrators feel empowered and get attention when a bystander is present in the situation. Research by [7] revealed that the presence of a bystander in bullying situations is important because the perpetrator can initiate his actions when his peers are in the situation. Another study by [11] revealed that bullies have the most self-confidence and are the strongest thus they enjoy this status which is considered a popular person among their peers. The results of this study are also in line with previous research by [15] which stated that there is a positive influence on the perception of bullies on the intensity of bullying in junior high school students in Makassar. In contrast to the results of this study, [26] revealed that bystanders do not play a major role in increasing bullying behavior. On the contrary, this study provides a solution that bystander can actually be an alternative to reduce the intensity of bullying behavior.

The presence of a bystander that allows perpetrators to carry out body shaming actions encourages the repetition of body shaming actions. In addition, the perpetrator also felt supported by a bystander who just watched without doing any help. Repeated acts of body shaming can be caused by the lack of care from the bystander to help or defend the victim. This is supported by research by [27] which explained that the recurrence of bullying is caused by the lack of moral concern from the bystander towards the victim, thus making the bystander rarely provide help by defending the victim. [5] Added that the bystander does not provide assistance to the victim because of the bystander's fear of the bully. This is supported by [5] which explained that bystanders 
actually feel worried about victims, but bystanders are more afraid if they get social consequences from bullies.

Based on the explanation above, it can be concluded that the bystander plays a significant role in the recurrence of body shaming. Perpetrators are confident, strong, powerful, and supported by a bystander who is present in a body shaming situation. The role of the bystander who only watch without providing help triggers the perpetrator to tolerate his actions. Bystanders who are present in this situation have the least concern and fear of the social consequences that will be labelled by the perpetrators of body shaming.

\section{CLOSING}

Based on the results of the research above, it can be explained that (1) the Bystander effect on psychology students in the city of Malang is in the medium category. In other words, the perception of the perpetrators of body shaming describes the presence of bystanders as individuals who are apathetic and do not care about the body shaming situation around them. (2) The intensity of body shaming in psychology students in Malang city is in the medium category. In other words, research respondents have a fairly high tendency to take body shaming actions. (3) The Bystander effect is able to play a significant role in the intensity of body shaming in psychology students in Malang City. This proves that the perception of body shaming perpetrators on the presence of a bystander can increase the occurrence of body shaming actions around them.

Recommendations for psychology students are expected to be more sensitive to acts of bullying, especially body shaming so that it can suppress the intensity of body shaming actions anywhere. Recommendations for further researchers are expected to examine the bystander effect associated with other variables because there are very few studies on the bystander effect. In addition, it is highly recommended to take more research samples in order to obtain varied data to further enrich the research. Finally, the research subjects used are expected to cover the wider community therefore the research results are not limited to a community and can be generalized.

\section{References}

[1] Labre MP. Adolescent boys and the muscular male body ideal. Journal of Adolescent Health. 2002;30(4):233-42. Available from: https://www.jahonline.org/article/S1054$139 \times(01) 00413-X / p d f$ 
[2] Komisaris Perlindungan Anak Indonesia. Sejumlah kasus bullying sudah warnai catatan masalah anak di awal 2020, Begini Kata Komisioner KPAl. 2020 February 10. Available form: https://Www.Kpai.Go.Id/Publikasi/Sejumlah-Kasus-Bullying-SudahWarnai-Catatan-Masalah-Anak-Di-Awal-2020-Begini-Kata-Komisioner-Kpai

[3] Rigby K. What harm does bullying do? Jurnal disajikan Dalam Children And Crime: Victims And Offenders Conference Convened By The Australian Institute Of Criminology And Held, Brisbane. 1999 June 17-18. Available from: https://www.researchgate.net/profile/ Ken_Rigby/publication/242084964_WHAT_HARM_DOES_BULLYING_DO/links/ Odeec52e73576a820f000000.pdf

[4] Susanto A. Indonesia masuk kategori darurat bullying di sekolah. 2014 October 23. Available from: https://www.beritasatu.com/mutia-nugraheni/gayahidup/219515/indonesia-masuk-kategori-darurat-bullying-di-sekolah

[5] Coloroso B. Stop bullying: Memutus rantai kekerasan anak dari prasekolah hingga SMU. Terjemahan Santi Indra Astuti. Jakarta: Serambi Ilmu Semesta; 2007.

[6] Ahmed E. Understanding bullying from a shame management perspective: Findings from a three year follow-up study. British Journal Of Educational And Child Psychology. 2006;23:26-40.

[7] Hawkins DL, Pepler D, Craig WM. Peer interventions in playground bullying. Social Development. 2001;10:512-527. Available from: https://www.prevnet.ca/sites/prevnet.ca/files/research/PREV-Hawkins-etal-2001Communique-peer-intervention.pdf

[8] Cowie H. Understanding the role of bystanders and peer support in school bullying. International Journal of Emotional Education. 2014;6(1):26-32.

[9] Ardianti C. Identifikasi faktor-faktor yang mempengaruhi bullying [Skripsi tidak dipublikasikan]. Semarang: Fakultas Psikologi Universitas Katolik Soegijapranata Semarang; 2009. Available from: http://eprints.unika.ac.id/ 17550/1/03.40.0097_Clementia_Ardianti.pdf.

[10] Caravita S, Diblasio P, Salmivalli C. Unique and interactive effects of empathy and social status on inovlvement in bullying. Social Development. 2009;18:140-163

[11] Graham S, Bellmore AD. Peer victimitation and mental health during early adolescence. Theory into Practice. 2007;46:138-146.

[12] Sears DO, Freedman JL, Peplay LA. Psikologi sosial edisi kelima jilid 2. Jakarta: Erlangga; 1999.

[13] Widyastuti Y. Psikologi sosial. Yogyakarta: Graha ilmu; 2014. 
[14] Safitri AM. Sering tidak sadar, ini 4 tanda anda suka mengejek fisik orang lain (Body shaming). HelloSehat. 2018 December 26. Available from: https://hellosehat.com/hidup-sehat/psikologi/ciri-body-shaming-adalah/\#gref

[15] Halimah A, Khumas A, Zainuddin K. Persepsi pada bystander terhadap intensitas bullying pada siswa SMP. Jurnal Psikologi. 2015;42(2):129-140.

[16] Fredrickson BL, Roberts TA. Objectification theory: Toward understanding women's lived experiences and mental health risks. Psychology of Women Quarterly. 1997;21:173-206. Available from: Https://Www.Researchgate.Net/Publication/ 258181826_Objectification_Theory_Toward_Understanding_Women's_Lived_Experience

[17] Rachmah E, Baharuddin F. Faktor pembentuk perilaku body shaming di media sosial. Seminar Nasional \& Call Paper Psikologi Sosial, Fakultas Pendidikan Psikologi

[18] Rahayu EP. Dampak penerimaan pesan "body shaming" terhadap "self confidence" remaja perempuan di media sosial instagram. Commercium. 2019;2(1). Available from: https://jurnalmahasiswa.unesa.ac.id/index.php/Commercium/article/view/30057

[19] Hestianingsih. Stop body shaming sesama wanita di media sosial, kamu bisa dipenjara. 2018 Nov 22. Available from: https://wolipop.detik.com/health-and-diet/d4312143/stop-body-shaming-sesama-wanita-di-media-sosial-kamu-bisa-dipenjara

[20] Santoso A. Polisi tangani 966 kasus body shaming selama 2018. 2018 Nov 28. NewsDetik.com. Available from: https://news.detik.com/berita/d-4321990/polisitangani-966-kasus-body-shaming-selama-2018

[21] Lestari S. Bullying or body shaming? Young women in patient body dysmorphic disorder. Philanthropy: Journal of Psychology. 2019;3(1):59-66.

[22] Hartaji DA. Motivasi berprestasi pada mahasiswa yang berkuliah dengan jurusan pilihan orangtua. Fakultas Psikologi Universitas Gunadarmal; 2012. Available from: Http://Docplayer.Info/34427591-Motivasi-Berprestasi-Pada-MahasiswaYang-Berkuliah-Dengan-Jurusan-Pilihan-Orang-Tua.Html

[23] Amri DTS. Kecenderungan perilaku body shaming dalam serial Netflix “Insatiable". Jurnal Audiens. 2020;1(1):100-106. Available from: https://borang.umy.ac.id/index.php/ja/article/view/8198

[24] Uale BP. Teachers as bystanders: The effect of teachers' perceptions on reporting bullying behavior [Doctoral Dissertation]. California, USA: University Of Southern California; 2010.

[25] Hansen B. Bullies and bystanders. 2013. Available from: http://www.yourtango.com/ experts/brock-hansen/bullies-and-bystanders-expert)

[26] Zahra AA. Upaya mengurangi perundungan melalui penguatan bystanders Di SMP B Yogyakarta. In: Proceedings of 6th University Research Colloquium 2017: Kontribusi 
Perguruan Tinggi dalam mewujudkan Sustainable Development Goals. Universitas Muhammadiyah Magelang. Magelang, Indonesia 9 September 2017 2017;17-22.

[27] Thornberg R, Jungert T. Bystander behavior in bullying situations: Basic moral sensitivity, moral disengagement, and defender self-efficacy. Journal Of Adolescence. 2013;3(36):475-483. 